\title{
Management Accounting
}




\section{MACMILLAN TITLES OF RELATED INTEREST}

Introduction to Accountancy and Finance

Richard Briston

Advanced Management Accounting Problems

Kenneth P. Gee

The Structure of Consolidated Accounting (2nd edition)

H. K. Jaeger

Cost Accounting: analysis and control

W. Armand Layne (with Colin Rickwood)

Financial Accounting and Reporting

Robin John Limmack

Accounting in an Inflationary Environment (2nd edition)

Robert W. Scapens 


\section{MANAGEMENT ACCOUNTING}

\section{A Review of \\ Contemporary \\ Developments}

Robert W. Scapens

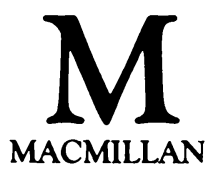


(C) Robert W. Scapens 1985

Softcover reprint of the hardcover 1st edition 1985 978-0-333-35931-0

All rights reserved. No reproduction, copy or transmission of this publication may be made without written permission.

No paragraph of this publication may be reproduced, copied or transmitted save with written permission or in accordance with the provisions of the Copyright Act 1956 (as amended).

Any person who does any unauthorised act in relation to this publication may be liable to criminal prosecution and civil claims for damages.

First published 1985

Published by

Higher and Further Education Division

MACMILLAN PUBLISHERS LTD

Houndmills, Basingstoke, Hampshire RG21 2XS

and London

Companies and representatives

throughout the world

ISBN 978-0-333-35932-7

ISBN 978-1-349-18054-7 (eBook)

DOI 10.1007/978-1-349-18054-7 


\section{Contents}

Preface ix

\section{PART 1 MANAGEMENT ACCOUNTING: THEORY AND PRACTICE}

1 Introduction 3

The Conventional Wisdom 7
2.1 The Rise of Management Accounting 7

2.2 Scope of Management Accounting 10

2.3 Planning 12

2.4 Cost Classifications 15

2.5 Control 16

2.6 Costing 19

2.7 Divisionalised Organisations 20

2.8 Some Implied Assumptions of Management Accounting 22

3 Management Accounting Practice 25

\section{PART II EXTENSION OF QUANTITATIVE MODELS}

Statistical Regression Analysis $\quad 33$
4.1 The Use of Regression Analysis 34 
4.2 The Least Squares Regression Model 35

4.3 Some Other Problems 40

4.4 Testing the Adequacy of the Model 41

4.5 Use of the Model 46

4.6 Multiple Regression 48

4.7 Some Concluding Remarks 56

5 Cost-Volume-Profit Analysis 59

5.1 The Simple Model 60

5.2 Assumptions 62

5.3 Multiproduct C-V-P Analysis 64

5.4 The Simple Model with Uncertainty 66

5.5 Limitations 69

5.6 Multiproduct C-V-P Analysis Under Uncertainty 70

5.7 Uncertainty in Other Variables 72

5.8 Some Final Points 73

6 Variance Investigation Models 75

6.1 The Decision Theory Approach 76

6.2 Determining Probabilities 78

6.3 An Illustration 79

6.4 Bayes' Theorem 80

6.5 Discussion 83

\section{PART III INFORMATION COSTS AND BENEFITS}

$7 \quad$ Value of Information 91

7.1 Information Costs 91

7.2 The Value of Information 93

7.3 An Ice-cream Manufacturer 96

7.4 The Value of Imperfect Information 100

7.5 Discussion 106

Q Information Economics 108

8 8.1 The Ice-cream Manufacturer's Problem 108

8.2 The Role of Information 112

8.3 Bayes' Theorem 113

8.4 Value of Information 114

8.5 The Selection of an Information System 116

8.6 Discussion 117 
(9) Simplified Models and Empirical Studies 121

9.1 Revisions to the 'Complete' Analysis 122

9.2 Form of Model Simplification 123

9.3 Illustration 125

9.4 Implications for Empirical Work 128

9.5 A Change of Emphasis 131

9.6 Some Comments on Behavioural Accounting Research 134

\section{PART IV CURRENT AND FUTURE DEVELOPMENTS}

10 Cost Allocation Models 139

10.1 Arbitrariness of Allocations 140

10.2 Allocations of Joint Costs 143

10.3 Allocations of Common Costs 152

10.4 Other Approaches 162

10.5 Possible Reasons for Cost Allocations 164

Agency Theory and Management Accounting 167

11.1 The Agency Theory Framework 168

11.2 Information Asymmetry 172

11.3 Limitations of the Agency Model 173

11.4 Some General Implications of Agency Theory 174

11.5 Specific Management Accounting Implications of Agency Theory 177

11.6 The Contribution of Agency Theory 180

Some Possible Future Developments 184

12.1 Some Implications of the Change of Emphasis 186

12.2 Directions for the Future 188

References 191

Index 197 
For W. R. Scapens 


\section{Preface}

In 1982 I wrote a survey paper on management accounting for the Economic and Social Research Council (ESRC - at that time, SSRC). My objective in writing that paper was to survey the development of management accounting in the academic literature over the preceding twenty years or so in an attempt to assess the current state-of-the-art. The paper reviewed contemporary developments in management accounting research in quite broad terms and when I decided to use the general themes of the survey in my undergraduate teaching, I found it necessary to give students a number of lectures to introduce them to the concepts and techniques which have been discussed in the research literature. This book has arisen out of these lectures.

Readers who are familiar with the management accounting research literature are urged to read the survey paper, which has now been published along with two other ESRC-commissioned surveys in Management Accounting, Organizational Theory and Capital Budgeting by R. W. Scapens, D. T. Otley and R. J. Lister (Macmillan/ESRC, 1984). This present book is intended for readers who have not explored the research literature in any depth, but have some knowledge of standard textbook treatments of the subject. The contents of the book are aimed at second/third year students of management accounting and others who want to understand the directions of contemporary management accounting research. 


\section{Preface}

It is assumed that the reader has had at least an introductory course in management accounting and is familiar with the topics typically covered in introductory textbooks. But a reader who has studied or is currently studying an intermediate management accounting textbook will also find this book very relevant. An attempt has been made to limit the complexity of highly mathematical topics - where mathematics are used they are kept as simple as possible and the interested reader is referred to more detailed treatments elsewhere. In general, emphasis is given to the interpretations and conclusions which can be drawn from mathematical analyses, rather than to the form of the analyses themselves.

No attempt is made to achieve a comprehensive coverage of all research which can be described as being within the field of management accounting. Certain important topic areas have been selected to illustrate the general nature of contemporary developments in management accounting research. Having completed the book, the reader should have an understanding of current academic thought in management accounting, a knowledge of where it has come from, and some ideas as to where it might lead.

I would like to express my gratitude to the ESRC for commissioning the survey paper which has led eventually to this book. In addition, my thanks are due to Professor Mike Bromwich, who first suggested that I should expand my survey paper into a book, and whose comments, criticisms and advice in the editorial process have contributed greatly to the end result. Mention should also be made of a number of my students who offered critical comments on earlier drafts. Finally, I would like to express my special thanks to my wife, Maureen, for her support and encouragement and for the many hours she spent word processing the material for this book. 